\title{
Kalkulator Untuk Mengukur Tingkat Kompetisi di suatu Industri, dengan menggunakan rumus Indeks Haryadi
}

\author{
Sigit Haryadi
}

\author{
Institut Teknologi Bandung \\ Januari 2018
}

Paper DOI: 10.17605/OSF.IO/WSQBE

CITATION: Haryadi, S. (2018, February 1). Kalkulator Untuk Mengukur Tingkat Kompetisi di suatu Industri, dengan menggunakan rumus Indeks Haryadi. Retrieved from osf.io/preprints/inarxiv/wsqbe

1. Alamat website:

http://sigitharyadi.net/id/multidicipline/haryadi-competitionindex-id/

\section{Penjelasan Tentang Metoda}

Metoda pengukuran tingkat kompetisi di suatu industri adalah dengan menggunakan rumus ini dibuat oleh Sigit Haryadi pada bulan April 2016, untuk memenuhi keinginan banyak orang terkait suatu metode yang lebih akurat dibanding metode eksisting yang dinilai kurang akurat, yaitu Herfinddahl-Hirschman Index.

Hasil yang diperoleh kalkultor ini adalah indeks kompetisi dan tingkat kompetisi dari suatu industri yang terdiri dari $\mathrm{N}$ buah provider atau pabrik, , dimana bila dari hasil perhitungan didapatkan indeks kompetisi $=1$ adalah menyatakan bahwa tingkat kompetisi adalah sempurna, indeks $=0.75$ adalah merupakan batas terendah tingkat kompetisi masih berada pada kondisi tingkat yang adil, indeks $=0.5$ merupakan batas dari tingkat kompetisi tak seimbang dan tingkat kompetisi tidak adil, dimana hasil perhitungan ini akan tetap akurat pada kondisi berapapun jumlah provider atau pabrik.

\section{Prosedur Menggunakan Kalkulator di Website}

I. Masukan $\mathrm{N}=$ jumlah provider atau pabrik, lalu di layar akan tersedia kolom isian seperti yang ditampilkan di halaman berikut ini. 
Banyaknya Provider atau Pabrik:

\section{CALCULATE}

HASIL PERHITUNGAN:

Banyaknya Provider atau
Pabrik $(\mathrm{N})$ :
Indeks Kompetisi:
Tingkat Kompetisi:

II. Isilah Market dari setiap provider atau pabrik, lalu tekan "CALCULATE" Maka anda akan mengetahui indeks dan tingkat kompetisi menggunakan metode yang dikembangkan oleh Sigit Haryadi, seperti yang ditampilkan di gambar berikut ini (misal jumlah provider atau pabrik $=3$ dengan market masing-masing adalah 35 Milyar, 40 Milyar dan 50 milyar).

Banyaknya Yrovider atau Habrik:

3

Provider 1 Market:

35

\begin{tabular}{l|l} 
Hrovider 2 Market: & 1,0
\end{tabular}

Provider 3 Market:

50

CALCULATE

CALCULATION RESULT:

\begin{tabular}{|l|l|}
\hline $\begin{array}{l}\text { 'I he Number of Provider or Hactory } \\
(\mathrm{N}):\end{array}$ & 3 \\
\hline Competition Index: & 0.92 \\
\hline Competition Level:: & Fair Competition \\
\hline
\end{tabular}




\section{Penjelasan cara perhitungan:}

1. Pertama, dihitung share dari market tiap provider, dengan menggunakan rumus berikut:

$$
\mathrm{S}_{i}=\frac{\text { Market }_{i}}{\sum_{i=1}^{N} \text { Market }_{i}}
$$

2. Lalu dihitung indeks kompetisi menggunakan rumus "Indeks Haryadi" berikut ini:

$$
H I=\frac{1}{\left[N^{*}\left\{\sum_{i=1}^{N} S_{i}^{2}+\sum_{i=1}^{N} \sum_{j=1}^{N}\left(S_{i}-S_{j}\right)^{2}\right\}\right]} ; i>j
$$

3. Lalu ditentukan tingkat kompetisi sebagai berikut: \{Tingkat Kompetisi adalah:

Sempurna; Adil; Tidak Seimbang; Tidak Adil; Tidak ada Keadilan sama sekali $\}$ adalah bersesuaian dengan nilai-nilai \{ Indeks Haryadi adalah: 1,0; 0,75-0,99; 0,50-0,74;0,49 $-(\mathrm{N}-1) /(2 * \mathrm{~N}) ;<(\mathrm{N}-1) /(2 * \mathrm{~N})\}$

\section{Daftar Pustaka:}

[1] Sigit Haryadi. (2017). The Equality Correlation Method. Researchgate. DOI: 10.13140/RG.2.2.10443.80169.

[2] Sigit Haryadi. (2017). Calculation of the Mobile Communication Competition using Haryadi Index. DOI: 10.13140/RG.2.2.15634.25280

[3] Sigit Haryadi. (2017). Haryadi Index and Its Applications in Science of Law, Sociology, Economics, Statistics, and Telecommunications. Penerbit Elex Media Komputindo. Jakarta. ISBN: 978-602-02-9895-5.

[4] Sigit Haryadi. (2017). Indeks Haryadi dan Penerapan di Ilmu Hukum, Sosiologi, Ekonomi, Statistik, dan Telekomunikasi. Penerbit Elex Media Komputindo, Jakarta. ISBN: 978-602-02-9896-2 